УДК 159.91

doi: 10.15330/ps.9.1.119-125

\author{
Олексій Сабадуха \\ Українська асоціація психосоматичної терапії \\ ov_sabadukha@ukr.net

\section{ПСИХОСОМАТИЧНИЙ ІНСТРУМЕНТАРІЙ: МЕТОД ТРАНСОСОБИСТІСНОЇ ТЕРАПІЇ ЯК СПОСІБ КОРЕКЦІї ФІЗИЧНОГО ТА ПСИХОЛОГІЧНОГО ЗДОРОВ'Я ЛЮДИНИ}

У статті теоретично обтрунтовано механізм виникнення та перебігу психосоматичних порушень, а також запропоновано авторський підхід у психосоматичній роботі - метод трансособистісної терапії, що дозволяє одночасно коригувати як фізичний, так і психічний стан людини.

Доведено, що свідоме переживання деструктивних думок, емоиій та почуттів обумовлює функиіональні порушення внутрішніх органів, що, у свою чергу, детермінує спазми та застійні процеси в різних частинах тіла (представницькі зони Захар'їна-Хеда). Метод трансособистісної терапії охарактеризовано як синтез тілесних, психологічних та духовних практик, результатом яких є позбавлення людини від деструктивних установок, емоиій та почуттів, формування конструктивного ставлення до себе, інших людей і соиіальних умов життя, а також корекиія функиіонального стану організму. Джерелами методу є логотерапія В. Франкла та психофізіологічні дослідження А. Корба. Психотерапевтичний ефект методу трансособистісної терапї забезпечується лікувальним масажем та трьома психологічними вправами: «Висловлювання почуття подяки», «Прийняття проблемної ситуації», «Самотрансиендениія».

Обтрунтовано, що активізаџія префронтальної кори та заспокоєння лімбічної системи - необхідна умова відновлення психологічного й фізичного здоров'я людини, на що й спрямований метод трансособистісної терапії. У стані активності префронтальна кора (свідоме) здатна контролювати імпульси смугастого тіла (підсвідоме), що є умовою духовного розвитку людини до особистісного рівня.

Ключові слова: метод трансособистісної терапії, смугасте тіло, підсвідомість, залежна людина, префронтальна кора, свідоме, особистість.

Постановка наукової проблеми. Проблема людського здоров'я завжди мала особливу вагу. В усі часи свого існування людина теоретично та практично освоювала нові тілесні, психологічні та духовні оздоровчі практики, удосконалювала методи профілактики здоров'я та лікування різних функціональних порушень. Суттєвим досягненням у запровадженні сучасних лікувально-оздоровчих практиках є те, що фахівці дедалі більше звертають увагу на цілісну природу людського організму, досліджують вплив психіки на фізичний стан людини. Психосоматика, вивчаючи психологічні причини виникнення фізичних розладів, набуває особливої актуальності серед інших медико-психологічних спеціальностей. Дослідженням психосоматичних зв'язків в організмі людини займалися філософи, психологи та медики різних часів: Ф. Александер, Г. Бергман, С. Боткін, В. Бройтігам, Й. Гейнрот, Г. Захар’їн, А. Корб, Н. Пезешкіан, В. Франкл, 3. Фройд та інші. Незважаючи на значний прогрес у розвитку психосоматичного напряму, малодослідженим залишається теоретичне підгрунтя механізму виникнення психосоматичних функціональних порушень, а також відсутній психосоматичний інструментарій для цілісної корекції здоров'я пацієнта, його фізичного та психічного стану.

Мета статті: теоретично обгрунтувати механізм виникнення та перебігу психосоматичних порушень, а також запропонувати авторський підхід у психосоматичній роботі - метод трансособистісної терапії, що дозволяє одночасно коригувати як фізичний, так і психічний стан людини. Джерелами методу $є$ логотерапія В. Франкла та психофізіологічні дослідження А. Корба.

Виклад основного матеріалу. Теоретичним підгрунтям механізму виникнення психосоматичних функціональних розладів пропонуємо вважати такі положення: 1) реальне, свідоме переживання деструктивних думок, емоцій та почуттів детермінує виникнення фізичних дисфункцій; 2) тривале переживання негативних думок, емоцій та почуттів перш за все відбивається на функціонуванні внутрішніх органів. Проаналізуємо ці положення детально. 
Положення перше. На сьогодні в широкому колі психосоматичних терапевтів уважається, що несвідомі, витіснені переживання $є$ головною причиною виникнення фізичних розладів. Так, наприклад, А. Менегетті, аналізуючи психологічні причини тілесних захворювань, пише, що «у несвідомому < ..> будь-який афект, що не знайшов відповідного втілення, залишається постійно діючим, життєвим та викривленим. Як наслідок, імпульс, що був знехтуваний свідомою системою, обов'язково житиме, зберігаючись у несвідомому, його дія матиме патологічний характер» [3]. Утім, реальне життя демонструє протилежні факти. У підсвідомій частині психіки (смугасте тіло) та в довготривалій пам'яті (гіпокамп) можуть бути «записані» пережиті психологічні травми, проте, незважаючи на це, у певний момент увага людини (поясна кора) може бути зосереджена на позитивних переживаннях: наприклад, почуттях радості та любові. На фізичному рівні позитивні емоції та почуття проявляються в таких фізіологічних процесах: заспокоюється лімбічна система, нормалізується дихання та збільшується обсяг кисню в крові, покращується тонус м'язів та судин, прискорюється кровообіг, а отже - поліпшується обмін речовин. Тобто організм реагує не на минулі переживання, а на думки, емоції та почуття, на яких зосереджена в даний момент увага людини. 3 цього приводу нейробіолог А. Корб зазначає: «Передня поясна кора подібна до монітору комп'ютера. На його жорсткому диску зберігається багато різної інформації. Але на вашому моніторі відображається лише та іiі частина, яка вас цікавить i, нарешті, це визначає ваші дії...» [2]. Отож, організм людини відбиває те, на чому зосереджена ії свідомість, увага.

Звісно, стан свідомості, що впливає на наше тіло, може бути обумовлений впливом несвідомого. Проте кожна людина відповідно до рівня свого духовного розвитку [1, с. 74], здатна тією чи іншою мірою контролювати цей вплив. «Наші інстинкти <.. > лише «формують запит» на поведінку, тоді як наше «Я» приймає рішення, що врешті-решт робити з цим запитом. Саме наше «Я» здатне вирішувати й здійснювати вільний вибір <..> I так відбувається завжди незалежно від того, куди нас «тягне» сума несвідомих побудників - Воно» [7, с. 213]. На мові психофізіології зазначений механізм дослідив А. Корб. Він зазначає, що наші вчинки - це результат взаємодії між префронтальною корою, ядром та верхньою зоною смугастого тіла. Ядро та верхня зона подають імпульс, а префронтальна кора («Президент» нашого мозку) приймає рішення, що з цим імпульсом робити [2].

Варто підкреслити, що несвідоме найбільше впливає на життєдіяльність людини тоді, коли у неї інертна свідомість - відсутні конструктивні установки, цінності та смисли, а сама вона спонукається принципом задоволення. Принцип задоволення, що діє в межах підсвідомого (ядро смугастого тіла), може виявлятися настільки сильним, що йому вимушена підкорятися свідомість, тобто людина йде за своїми інстинктивними бажаннями, потягами, потребами й стає їхнім рабом. Про стан психіки таких людей 3. Фройд зауважує: «Стосовно Воно Я подібне вершнику, який повинен приборкати сильнішого від себе коня <..>. Як вершнику, якщо він не хоче розлучитися з конем, часто залишається лише вести його туди, куди йому хочеться, так і Я перетворює волю Воно на дію, ніби це було його власною волею» [8, с. 432]. За концепцією чотирьох рівнів духовного розвитку людини такий соціально-психологічний тип людини отримав назву - «залежна людина» [1, с. 76]. Натомість людина особистісного рівня духовного розвитку $[1$, с. 86] здатна силою своєї свідомості контролювати та коригувати підсвідомі імпульси. На психофізіологічному рівні цей процес виглядає так: «... медіальна префронтальна кора може проектувати свою активність на верхню ділянку смугастого тіла, а орбітофронтальна ділянка кори головного мозку проектується на сусіднє ядро. Це може виглядати спрощено, але виходить, що префронтальна кора коректує та моделює наші імпульси та звички. Це дає більші можливості контролювати власне життя, дозволяючи не залежати від минулого досвіду...» [2].

Отже, несвідоме й свідомість перебувають у постійному взаємозв'язку: підсвідомість (смугасте тіло) подає імпульси, а свідомість (префронтальна кора) приймає рішення, як урештірешт діяти. «Сильна» свідомість (притаманна людині особистісного рівня духовного розвитку $[1$, c. 85]), яка сповнена конструктивних установок, цінностей та смислів, дозволяє 
переборювати негативний вплив підсвідомого, формувати й активізувати лише позитивні підсвідомі звички та установки. «Слабка, інертна» свідомість (притаманна людині залежного та посереднього рівнів духовного розвитку [1, с. 80]) виявляється залежною від підсвідомих імпульсів, що діють за принципом задоволення, а також від негативних звичок. У будь-якому випадку формується певна концентрація думок, емоцій та почуттів, що впливають на фізичне самопочуття людини.

Положення друге. Суттєвою специфікою тривалого впливу переживань на фізичний стан людини $\epsilon$ те, що вони в першу чергу відбиваються на функціонуванні внутрішніх органів. Так, якщо людина сконцентрована на позитивних думках, емоціях та почуттях (конструктивній, суспільно значущій діяльності) - домінує парасимпатична нервова система як частина вегетативної, що уповільнює серцебиття, покращує роботу жовчного міхура, стимулює секрецію шлункового соку, ферментів підшлункової залози, покращує перистальтику кишечнику та процес травлення, а отже - прискорюється обмін речовин. Навпаки, якщо людина переживає негативні думки, емоції та почуття - домінує симпатична нервова система як частина вегетативної, що уповільнює слиновиділення, прискорює серцебиття, призупиняє секрецію шлункового соку та ферментів підшлункової залози, уповільнює перистальтику кишечника та процес травлення, а тому - уповільнюється обмін речовин. На фоні тривалого домінування симпатичної нервової системи відбуваються спазми тканин (судин, фасцій, м'язів, сухожиллів, зв'язок) та застійні явища, що стають передумовою розвитку різноманітних захворювань. Механізм впливу психічного стану на фізичний організм можна пояснити так. Лімбічна система сприймає інформацію про внутрішній стан організму та зовнішнє його середовище. На цю інформацію реагує гіпоталамус (структурна частина лімбічної системи), що керує вегетативною нервовою системою. Відповідно, якщо на лімбічну систему передається деструктивна інформація (негативні думки, емоції, відчуття, почуття) - гіпоталамус задіює симпатичну нервову систему, що спричинює спазми внутрішніх органів. Навпаки, якщо інформація подається конструктивна (позитивні думки, емоції, відчуття, почуття), - домінує парасимпатична нервова система, що активізує роботу внутрішніх органів. Отож, внутрішні органи першими реагують на психічний стан організму.

Усі внутрішні органи мають свої представницькі зони на тілі людини, що були винайдені та науково обгрунтовані лікарями: терапевтом Г. Захар'їним у 1889 р. та неврологом Г. Хедом у 1896 р. [4, с. 11]. Так, дисфункція будь-якого внутрішнього органу символізується спазмом тканин, застійними явищами та змінами шкіри на певних частинах тіла. Наприклад, функціональне порушення жовчного міхура означується болями між хребтом та верхньою зоною правої лопатки, головним болем у скронях та болючими відчуттями на зовнішній поверхні гомілки. Отже, у загальному вигляді ланцюг функціональних порушень в організмі людини є таким: стрес детермінує дисфункцію внутрішніх органів, що, у свою чергу, обумовлює спазми та застійні процеси в їхніх представницьких зонах (різних частинах тіла).

Для корекції фізичного та психічного стану людини запропоновано авторський метод психосоматичної роботи - метод трансособистісної терапії, що $є$ синтезом тілесних, психологічних та духовних практик, результатом яких є позбавлення людини від деструктивних установок, емоцій та почуттів, формування конструктивного ставлення до себе, інших i соціальних умов життя, а також корекція функціонального стану організму. Цей метод усуває такі психосоматичні проблеми, як неприйняття себе, образи, деструктивну фіксацію на минулому, тривожність, невроз нав'язливих станів, фобії, конфліктність (егоцентризм), апатію, депресію (екзогенну), почуття провини. Зазначмо, що ефективність запропонованого методу підтверджена практикою, тестуванням паціснтів до і після його застосування, а також їхніми позитивними відгуками. Варто підкреслити, що психофізіологічний механізм дії методу трансособистісної терапії повністю корелює 3 науковими дослідженнями та висновками нейробіолога А. Корба. 
Психотерапевтичний ефект методу трансособистісної терапії забезпечується лікувальним масажем та трьома психологічними вправами: «Висловлювання почуття подяки», «Прийняття проблемної ситуації», «Самотрансценденція». Проаналізуємо психофізіологічну дію кожного етапу роботи.

Завдяки виконанню лікувального масажу відбувається розслаблення центральної нервової системи та стимуляція вироблення важливих нейромедіаторів: серотоніну, дофаміну та окситоцину. Так, А. Корб зазначає, що за результатами досліджень, масаж активізує синтез серотоніну до 30\%, збільшує вміст дофаміну і зменшує рівень кортизолу, а окситоцин сприяє більш активному формуванню ендорфінів, що чинять знеболюючий вплив [2]. Отож, масаж допомагає оптимізувати роботу центральної нервової системи пацієнта, щоб наступні психологічні вправи справили більш глибокий терапевтичний ефект.

Вправа «Висловлювання почуття подяки» коригує психічний стан людини: допомагає свідомо сфокусувати увагу на позитивних аспектах свого життя, що сприяє формуванню конструктивного світогляду. Що більше ми вдячні, то більше ми цінуємо дійсність; відповідно - менше негативних емоцій, а особливо - критики, що чинить руйнівний вплив на організм людини. На психофізіологічному рівні почуття подяки активізує вироблення нейромедіаторів дофаміну та серотоніну [2].

Вправа «Прийняття проблемної ситуації» орієнтує людину приймати своє життя та його події: минулі, поточні, майбутні. «Коли ми більше не можемо контролювати і змінювати свою долю, тоді ми повинні бути готові прийняти іï» [6, с. 107]. Що більше людина бореться 3 неприємною життєвою ситуацією, яку вона не в силах змінити (зараз або взагалі), то більше вона (ситуація) буде викликати негативні емоції (неприйняття себе, образи, деструктивну заглибленість у минуле, тривожність, апатію, почуття провини тощо). «Що сильніше людина намагається уникнути неприємностей або страждання, то глибше вона занурюється в додаткові страждання» [6, с. 107]. Лише через прийняття проблемної ситуації зникає внутрішня напруга й приходить почуття спокою. На психофізіологічному рівні вербалізація та прийняття ситуації активізує вентролатеральну префронтальну кору мозку, і активність мигдалини знижується. Людина перестає емоційно реагувати на проблему, відтак формуються передумови свідомого осмислення проблеми і здатність до регулювання поведінки [2]. Важливо відзначити, що прийняття проблемної ситуації легше відбувається після позитивного емоційного підйому, за допомогою попередньої вправи на висловлення почуття подяки.

Вправа «Самотрансценденція» передбачає активізацію соціального, морального, духовного потенціалу пацієнта; орієнтує його на подолання старих, помилкових суджень й формування нових, конструктивних установок, цінностей та смислів, ухвалення рішення їх реалізувати. Підкреслимо, що самотрансценденцію людина здатна здійснити лише після особистісного прийняття проблемної ситуації й відновлення внутрішньої рівноваги. Варто зазначити, що в ідеальному варіанті процес самотрансценденції передбачає вихід на рівень особистісного буття [1, с. 85-86]. Так, для кожної психосоматичної проблеми є свої «антоніми» - ті конструктивні установки та цінності, на які слід орієнтуватися, щоб відновити психічне здоров'я, здійснити самотрансценденцію. Практичні аспекти вправи «Самотрансценденція» узагальнено в таблиці.

Основні психосоматичні проблеми та установки для їх усунення

Таблиия 1

\begin{tabular}{|l|l|l|}
\hline Психосоматична проблема & $\begin{array}{l}\text { Установки й цінності, необ- Здоровий психосоматичний } \\
\text { хідні для усунення } \\
\text { психосоматичної проблеми }\end{array}$ & стан \\
\hline $\begin{array}{l}\text { 1. Неприйняття себе, низька } \\
\text { самооцінка, самокритика }\end{array}$ & $\begin{array}{l}\text { Прийняти рішення поважати } \\
\text { свої якості, цінувати свою гід- } \\
\text { ність івірити в себе }\end{array}$ & Здорова любов до себе \\
\hline 2. Образи, гнів & Прийняти рішення зрозуміти & Прощення іншої людини \\
\hline
\end{tabular}




\begin{tabular}{|c|c|c|}
\hline & іншу людину & \\
\hline $\begin{array}{l}\text { 3. Деструктивна мисленнєва } \\
\text { заглибленість в минуле }\end{array}$ & $\begin{array}{l}\text { Прийняти рішення зосереди- } \\
\text { тися на улюбленій справі, } 3 \\
\text { якою можна рухатися далі }\end{array}$ & $\begin{array}{l}\text { Фокусування уваги на } \\
\text { сьогоденні та майбутньому }\end{array}$ \\
\hline $\begin{array}{l}\text { 4. Тривога, } \\
\text { нав'язливих станів, страх }\end{array}$ & $\begin{array}{l}\text { Прийняти рішення діяти без } \\
\text { категоричних очікувань: роби- } \\
\text { ти те, що потрібно, і будь що } \\
\text { буде (принцип парадоксальної } \\
\text { інтенції, В. Франкл) }\end{array}$ & Впевненість у собі \\
\hline $\begin{array}{l}\text { 5. Конфліктність: дратівли- } \\
\text { вість у спілкуванні, критика } \\
\text { інших, упертість, } \\
\text { егоцентризм }\end{array}$ & $\begin{array}{l}\text { Прийняти } \quad \text { рішення } \\
\text { враховувати } \\
\text { людей }\end{array}$ & $\begin{array}{l}\text { Конструктивні } \\
\text { навколишніми }\end{array}$ \\
\hline $\begin{array}{l}\text { 6. Апатія, депресія (екзоген- } \\
\text { на), екзистенційний вакуум } \\
\text { (втрата мети та смислу } \\
\text { життя) }\end{array}$ & $\begin{array}{l}\text { Усвідомлення смислу свого } \\
\text { житпя. Прийняти рішення нести } \\
\text { відповідальність за реалізацію } \\
\text { своїх життєвих цінностей перед } \\
\text { власною совістю }\end{array}$ & Інтерес і натхнення до життя \\
\hline 7. Почуття провини & $\begin{array}{l}\text { Визнати свою помилку(и) і } \\
\text { прийняти } \\
\begin{array}{l}\text { поводитися гідно } \\
\text { рішення }\end{array}\end{array}$ & Прощення себе \\
\hline
\end{tabular}

У процесі самотрансценденції відбувається робота 3 цілями і психотерапевтичними установками, тобто формується шлях розв'язання тієї чи іншої психологічної проблеми. На психофізіологічному рівні цей процес активізує префронтальну кору головного мозку, що усуває хвилювання й тривоги. Ухвалення рішень змінює сприйняття світу: воно надає впевненості в можливості виходу 3 кризових ситуацій, контролює й заспокоює лімбічну систему, знижує активність смугастого тіла, яке змушує нас покладатися лише на підсвідомі імпульси та звички [2]. Підкреслимо, що механізм проведення вищенаведених психологічних вправ передбачає спочатку виконання їх подумки (робота з психотерапевтичними образами), а потім уголос (психотерапевтична бесіда за протоколом).

Таким чином, трансособистісна терапія дозволяє водночас ефективно коригувати фізичний та психологічний стани людини: відбувається розслаблення центральної нервової системи, м'язів, а також викорінення хибних конструктів (Дж. Келлі) і заміна їх на конструктивні установки, цінності та смисли. Пацієнт у процесі терапії постає активним суб'єктом діяльності - психосоматичний терапевт активізує його внутрішній потенціал $\mathrm{i}$ спрямовує на впровадження психологічних та соціальних змін. Метод трансособистісної терапії, перш за все, орієнтований на конструктивну трансформацію свідомості людини, формується почуття власної відповідальність за вирішення життєвих завдань, тоді як психоаналітичні підходи змушують шукати причину своїх невдач у минулому, перекладаючи відповідальність на своїх батьків, вихователів, соціальне оточення. Щодо цього кіномитець А. Тарковський застерігає: «Ми надаємо надмірне значення ролі дитинства. Манера психоаналітиків дивитися на життя крізь дитинство, знаходити в ньому пояснення усьому - це один із способів інфантилізації особистості» [5].

Висновки. Психосоматика як науковий напрям у медицині та психології розвивається достатньо швидко, особливо враховуючи ії прикладний аспект. Утім, психосоматичні терапевти для адекватного з'ясування причинно-наслідкових зв'язків в організмі людини мають переосмислити теоретичне підгрунтя механізмів виникнення психосоматичних функціональних розладів. У загальному вигляді його можна сформулювати так: свідоме переживання деструктивних думок, емоцій та почуттів (пасивна префронтальна кора й активна лімбічна 
система) обумовлює функціональне порушення внутрішніх органів (активний симпатичний відділ вегетативної нервової системи), що, у свою чергу, детермінує спазми та застійні процеси в різних частинах тіла (представницькі зони Захар'їна-Хеда). Активізація префронтальної кори та заспокоєння лімбічної системи - необхідна умова відновлення психологічного й фізичного здоров'я людини, на що й спрямований метод трансособистісної терапії. У стані активності префронтальна кора (свідоме) здатна контролювати імпульси смугастого тіла (підсвідоме) та формувати у верхній зоні смугастого тіла нові корисні звички (змінювати характер підсвідомого), що є умовою духовного розвитку людини до особистісного рівня.

1. Гречаний, О. Ф., Сабадуха, В. О. (2015). Філософія здібностей у контексті пріоритету духовного над матеріальним. Луганськ: Вид-во СНУ ім. Володимира Даля.

2. Корб, А. (2018). Восходящая спираль. Как нейрофизиология помогает справиться с негативом и депрессией шаг за шагом. Взято 3 http://loveread.ec/view_global.php?id=59347.

3. Менегетти, А. (2018). Психосоматика. Взято 3 http://loveread.ec/read_book.php?id=48906\&p=7.

4. Огулов, А.Т. (2010). Азбука висиеральной терапии. М.: Предтеча.

5. Тарковский, А. (2018). Последнее интервью Андрея Тарковского «Красота - символ правды». Взято 3 http://tarkovskiy.su/texty/Tarkovskiy/interwiu.html.

6. Франкл, В. (2015). Воля к смыслу. М.: Альпина нон-фикшн.

7. Франкл, В. (1990). Человек в поисках смыслла. М.: Прогресс.

8. Фрейд, 3. (1990). Психология бессознательного. М.: Просвещение.

\section{REFERENCES}

1. Grechanij, O. F. (2015). Filosofiya zdibnostej u konteksti prioritetu duhovnogo nad materialnim [Philosophy of abilities in the context of the priority of spiritual over material]. Lugans'k : Vid-vo SNU im. Volodimira Dalya. (ukr).

2. Korb, A. (2015). Voskhodyashchaya spiral. Kak nejrofiziologiya pomogaet spravit'sya s negativom i depressiej shag za shagom [Upward spiral. How neurophysiology helps to cope with negativity and depression step by step]. Retrieved from http://loveread.ec/view_global.php?id=59347. (rus).

3. Menegetti, A. (2009). Psihosomatika [Psychosomatics]. Retrieved from http://loveread.ec/read_book. php?id=48906\&p=7. (rus).

4. Ogulov, A. T. (2010). Azbuka visceralnoj terapii [ABC of visceral therapy]. M.: Predtecha. (rus).

5. Tarkovskij, A. (1986). Poslednee intervyu Andreya Tarkovskogo «Krasota - simvol pravdy» [The last interview with Andrey Tarkovsky «Beauty is a symbol of truth»]. Retrieved from http://tarkovskiy.su/texty/ Tarkovskiy/interwiu.html. (rus).

6. Frankl, V. (2015). Volya k smyislu / [Will to sense]. M.: Alpina non-fikshn (rus).

7. Frankl, V. (1990). Chelovek v poiskah smysla [Man in search of meaning]. M.: Progress. (rus).

8. Frejd, Z. (1990). Psihologiya bessoznatelnogo [Psychology of the unconscious]. M.: Prosveshchenie (rus).

\section{Oleksiy Sabadukha \\ PSYCHOSOMATIC INSTRUMENTS: THE METHOD OF TRANSPERSONALTHERAPY AS A WAY TO CORRECT THE PHYSICAL AND PSYCHOLOGICAL HEALTH OF A PERSON}

The theoretical basis of the mechanism of occurrence and passing of psychosomatic disorders has been formulated in the article. Also there is the author's approach in psychosomatic work proposed - a method of transpersonal therapy that allows to correct simultaneously both physical and psychological state of a person.

It is shown that the conscious experience of destructive thoughts, emotions and feelings can cause functional disorders of the inner organs, which, in turn, determines cramps and stagnant processes in different parts of body (representative areas by Zakharyin - Ged).

The method of transpersonal therapy is characterized as a synthesis of bodily, psychological and spiritual practices and the result of which is the purification of a human's psyche from destructive settings, emotions and feelings. It is helpful in the formation of a constructive attitude towards oneself, others and social conditions of life, as well as the correction of the functional state of the organism. The method is based on Victor Frankl's logotherapy and psychophysiological studies by A. Corb. The psychotherapeutic effect of the method of transosomal therapy is provided by a therapeutic massage and by three psychological exercises: "Expressing a sense of gratitude", "Acceptance of a problematic situation», «Self-transcendence».

It is substantiated that activating the prefrontal cortex and calming the limbic system is a necessary condition for the restoration of psychological and physical health of a person, and the method of transpersonal therapy is just directed at this. In a state of activity, the prefrontal cortex (conscious) is able to control the impulses of the striatum (the physical base of subconscious), which is a condition of spiritual development of a human to a level of a person. 
Keywords: method of transpersonal therapy, striatum, unconscious, dependent person, prefrontal cortex, conscious, personality. 